\title{
Research on China's Social Governance Mode Transformation and Upgrading in Supply-Side Reform Field-From the Perspective of Public Management
}

\author{
Xiaohan Li \\ School of Government, Beijing Normal University, Beijing, China \\ Email: shinelee1991@163.com
}

How to cite this paper: Li, X. H. (2017). Research on China's Social Governance Mode Transformation and Upgrading in Supply-Side Reform Field-From the Perspective of Public Management. Chinese Studies, 6, 188-200.

https://doi.org/10.4236/chnstd.2017.63019

Received: July 31, 2017

Accepted: August 19, 2017

Published: August 22, 2017

Copyright $\odot 2017$ by author and Scientific Research Publishing Inc. This work is licensed under the Creative Commons Attribution International License (CC BY 4.0).

http://creativecommons.org/licenses/by/4.0/

\begin{abstract}
Supply-side reform has provided an advance institutional environment for the transformation and upgrading of social governance mode in China. In fact, supply-side reform requires the transformation and upgrading of social governance mode, while the latter is an inherent process of the former; supplyside reform and social governance mode's transformation and upgrading are serving for each other as important impetus, making progress during their interaction. Based on the polycentric governance mode theory, holistic governance theory and social quality theory, the supply-side reform of government should proceed in social governance subject, system design and public service supply. In the context of supply-side reform, social governance mode transformation should stick to the principle of "addition, subtraction, multiplication, and division": with the "addition effect" of the collaboration between supply-side reform and social governance mode transformation, the singlecenter social governance mode will be transformed to polycentric governance mode; with the "subtraction effect" of administrative intervention, the government-dominated governance mode will be transformed to governmentguided mode; with the "multiplication effect" of institutional innovation, the campaign-style governance mode will be transformed into institutional mode; with the "division effect" of compulsory control, the control-stabilization governance mode can be transformed to social quality governance mode.
\end{abstract}

\section{Keywords}

Supply-Side Reform, Social Governance Mode, Transformation, Management Innovation 


\section{Introduction}

It is known that the reform of supply-side is generated from economic field and aims at promoting the quality of supply and boosting structural adjustment with the reform. However, the economic society of China is now confronted by the practical contradiction between the rapid growth of public demand and the undersupply of public service. The boost of supply-side reform is not only the key to solve social contradictions and to construct service-oriented government, but also an important engine to achieve rapid growth of economy. Therefore, the essence of supply-side reform is to bring forth new ideas in social governance system and to accelerate the transformation and upgrading of social governance mode. But the existing researches on supply-side reform are mainly focusing on economic fields. Supply-side reform is rarely analyzed from the perspective of public management, let alone social governance mode transformation.

\section{The Coupling Relationship between Supply-Side Reform and Social Governance Mode Transformation and Upgrading}

Schultz, an American economist, believed that any institutions are responses to the existing demands in practical life. As China stepped into "new normal" era, the economy has been growing steadily for a long time, but still facing a series of structural contradictions in this new stage of transformation and upgrading. Some systems and mechanisms are severely lagging behind the current development, which poses urgent demands for the supply of Chinese government innovation system and the transformation of social governance mode. According to the present policy environment, supply-side reform has provided an advance institutional environment for the transformation and upgrading of social governance mode in China, while the transformation and upgrading of social governance mode will become an important component of the effective practical response to supply-side reform. Supply-side reform is the social basis, analysis framework, and ultimate concern for the transformation and upgrading of social governance mode.

"Integrity, people-oriented, and social quality" are the value origin of and logic link between supply-side reform and social governance mode transformation. In general, the main object of supply-side reform is to further simplify government agencies and delegate business management rights to enterprises; the emphasis of the reform is to innovate institutional supply, namely, the innovation of government's governance patterns. In a nutshell, supply-side reform is bound to the transformation and upgrading of social governance mode. Meanwhile, the transformation and upgrading of social governance mode should be a spontaneous process of supply-side reform. Logically speaking, there is a coupling relationship between supply-side reform and social governance mode transformation and upgrading (Figure 1): management risk of traditional social management mode $\rightarrow$ failure of social management mode $\rightarrow$ supply-side reform $\rightarrow$ 


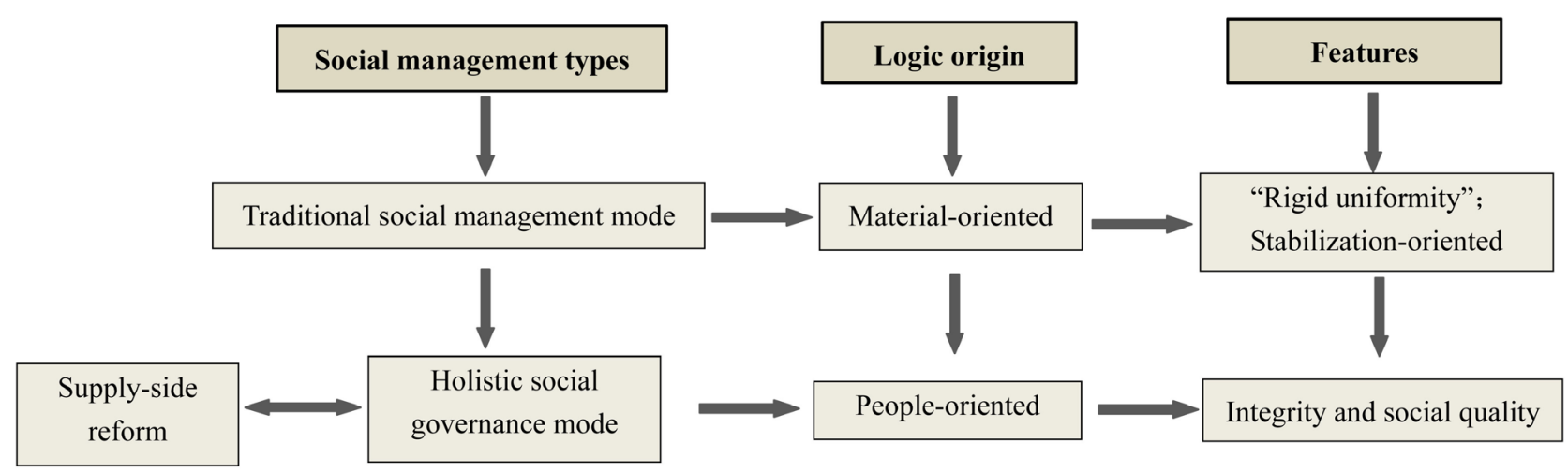

Figure 1. Coupling relationship between supply-side reform and social governance mode's transformation and upgrading.

transformation and upgrading of social management mode $\rightarrow$ holistic social governance mode $\rightarrow$ supply-side reform.

Various and many strategic and systematic problems emerge as the reform deepens, requiring professional solutions and innovative governance mode. The government should clarify their right limits and social governance should stick to the principle of "addition, subtraction, multiplication, and division". More specifically, the administrative departments should apply "addition" to collaboration, "subtraction" to administrative intervention, "multiplication" to system innovation, and "division" to compulsory control.

\section{Theoretical Basis of Social Governance Mode Transformation and Upgrading in Supply-Side Reform Field}

\subsection{Polycentric Governance Mode Theory-Supply-Side Reform of Social Governance Subject}

The word "polycentric" first appeared in The Logic of Liberty by Michael Polanyi, and then the polycentric governance theory was proposed by Vincent Ostrom and Elinor Ostrom based on in-depth theoretical and empirical analysis. According to polycentric theory, there are multiple subjects for governance and public service supply, which jointly govern public affairs, face the challenge of public governance, and provide all-around public service through competition and cooperation. It is a theory advocating fair competitions among multiple governance centers or service centers. With the pressure of competition and the complementation of cooperation, citizens are endowed with wider and more open free options, which can improve the quality of public service. Compared with the single-subject governance mode in traditional centralization system, "polycentric governance" can effectively reduce the "free ride" phenomena and avoid "the tragedy of public-owned". This way, the decisions will be more scientific and reasonable. In brief, polycentric governance theory is a solid theoretical basis for the simplification of government agencies, the delegation of business management rights, the combination of "delegation" and "management", and the innovative design of the system. 


\subsection{Holistic Governance Theory-Supply-Side Reform of System Design}

Holistic governance was derived from the decline of new public management and the rapid development of information technology. The logical origin of holistic governance is the solution to a problem, aiming at solving the deviation and cracking between governance targets and behaviors caused by fragmented governance and campaign-style governance. "Public ethic and value", "system design", and "trust" are the main focuses of holistic governance theory. According to Peng Jinpeng, holistic governance is a kind of government integral operation that takes network service as its organizational form and aims at fixing the problems in people's life and improving their living standards (Peng Jinpeng, 2005). The value orientation of system design moulds and determines the value choice of social governance, which needs to bridge the gap existing between the targets and behaviors of the governance process. The main idea is the generalized and sustainable system design. Holistic governance theory has provided a reliable theoretical basis and discourse platform for the system design of social governance in the context of supply-side reform, which has great practical significance for the improvements of campaign-style governance.

\subsection{Social Quality Theory-Supply-Side Reform of Public Service Supply}

Social quality theory was proposed in the EU Conference in July 1999. In this conference, it was declared that European society is expected to be a success in economic field, and the European Union is striving to improve the social quality of European society by enhancing social justice and social participation (Beck et al., 2001). Since then, the phrase "social quality" attracted scholars' attention and gradually expanded during their discussions. In social quality theory, social quality is indexed; a systematic theoretical framework for the evaluation of "social quality" is established (Figure 2) (Lin Ka, 2010), which assesses social quality from four dimensions, including social economic insurance, social solidarity, social integration, and social entitlement. From the perspective of social system

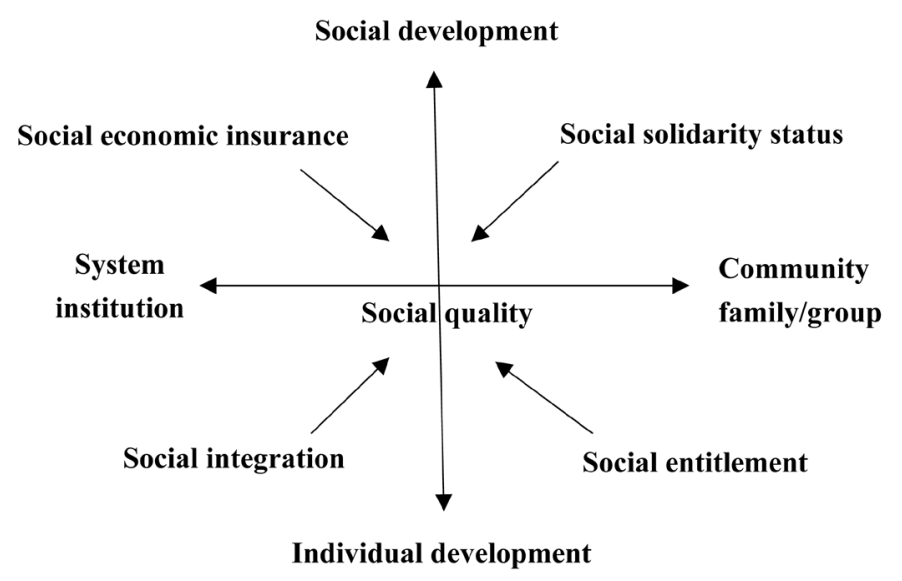

Figure 2. Conceptual framework of social quality. 
and institution, social quality is mainly reflected by social economic insurance level and social solidarity degree; as regards individuals, social quality is represented by the equalization and openness of citizens' chance endowed by their society as well as the social integration (Lin Ka, 2010). Nowadays, Chinese government emphasizes the importance of the "process" during social governance, because social governance is conducted in the context of social economy that changes continuously. Therefore, it is important to pay attention to the dynamics, expansibility, and continuity of social governance. Meanwhile, the government should abandon the governance mode of "rigid uniformity" and "campaign-style" governance. Social quality theory presents natural theoretical responsiveness and pertinence to the transformation status of China's social governance at present stage.

\section{Primary Disadvantages of Traditional Social Management Mode in Supply-Side Reform Field}

In the past three decades, Chinese economy embraced its golden era of rapid growth with the implementation of reform and opening-up policy and institutional transition. However, the development of social management was still lagging behind. As institutional transition deepens, the social interest relationship is further complicated and the disadvantages of traditional social management mode becomes more distinct.

\subsection{Single-Center Management Mode-Single Orientation of Governance Subject}

In traditional social management mode, government is the unique subject, serving as the supplier of social service and the first person responsible for social management. Meanwhile, the government is the final undertaker of social risks. All the social contradictions circle around the government, while various market forces and social forces rely on or attach themselves to the government, thus resulting in a situation of "strong government and weak society". In certain stages, this kind of management structure had positive effects on the development of China's economic society. But with the progress of the times, this management system is no longer fit to the integral development of the social. The government monopolized all the responsibilities of social management for a long period of time. In real life, government responsibility equals to government undertaking. Social organizations and citizens are excluded from the design, conception and practice of the system. The single-center mode intensifies "social exclusion", leading to the erosion and extrusion of social self-governance by government powers.

Society is formed by multiple social stratums and groups. Different stratums and groups have varied political appeals, social status, and living demands. For this reason, the subject of social governance should be diversified to include different social groups and citizens in social governance, and enable them to share the development achievements. Although there are thousands of social groups 
and autonomous organizations in China, most of them are related to the government or completely rely on government authorities. These organizations lack of interest expression mechanism and their responsibility scope is restricted to the implementation of government policies. In other words, the actual power is still in the hands of the government, which would restrain the expression of social consciousness. Consequently, it would suppress the development of social self-governance, the subject consciousness of the citizens, their enthusiasm for politics as well as their sense of social responsibility. Single-center management mode, on the other hand, would provide advantageous conditions for power rent-seeking and corruption.

\subsection{Government-Guided Governance Mode-Control Orientation of Governance Subject}

Historically, the birth of a government is always accompanied by the mission of social control, while the social control system gradually matures and improves during the long development process of the government. It is believed that the history of a government is the history of government control reinforcement (Zhang Kangzhi, 2012). Government departmentalism is the cause of monopolistic social management and arrogant administration, which further lead to the formation of centralized system. Power centralization and democracy are hot topics among people for a long time. There is no doubt that power centralization has the advantage of rapid mobilization and strong emergency capability in specific conditions, but it can only satisfy societies with low complexity and slow variation speed. When facing complex and fast-changing modern society, power centralization is no longer a useful tool to enhance control but a reflection of the government's deficiency.

The government tends to make attempts to stabilize social order by enhancing social control, which would always fail and eventually lead to social disorder. Quan Zhongxie believed that people are now living in "an era of paradox" (Quan Zhongxie, 2008). People are filled with longing for development and are making unremitting efforts for social development, but the results are quiet unexpected and opposite. Paradox would emerge when there is no consensus among administrators about the policy in implementation, such as the contradiction between economic development and environmental protection, administrative efficiency and administrative efficacy. In order to strengthen the control over society, the government will have to invest more operation costs (e.g. manpower and financial resources) in social management, thus leading to the swelling of government scale.

If the government defines its functions as "dominant" and "control", the expansion of manpower and institutions will be necessary, thus resulting in the swelling of government scale, which would then become a heavy burden to the control system and even endanger it. Traditional social management mode has blind faith in the power of enforcement, which leads to continuous tension between the government and the citizens during social management and reduces 
the social trust in the government. The government-guided governance mode is no doubt an opposite of the current reform policy advocating the simplification of government agencies, the delegation of business management rights, and the combination of "delegation" and "management".

\subsection{Campaign-Style Governance Mode-Irrational Orientation of System Design}

Social management in China has a strong preference for campaign-style governance mode with heavy administrative color. This is caused by the external environment, the national situation of dual transition, and the influence of traditional management system. Campaign-style governance mode is a kind of abnormal policy-based governance mode characterized by the conscious mobilization of governance subject and lacking of systematic rationality. In this context, local governments driven by political achievements tend to draw up rigid regulations and apply stopgap measures to cope with changes, trying to accomplish the targets in one rectification action. This abnormal governance mode seems to produce innumerable great achievements in short-term. However, these achievements are transitory and lack of continuity. Furthermore, these "top-down" administration-based unilateral governance measures can hardly solve the existing problems due to the lack of top-level designs, legal safeguard and supporting systems. Even worse is the reemergence of the problem. In this case, the government will find itself trapped in endless loop of campaign-style governance.

According to the findings of Feng Zhifeng, the features of campaign-style governance in China are the authority of governance subjects, the specificity of governance objects, the motility of governance patterns, the temporality of governance time, the predetermination of governance targets, the reemergence of governance results, the compulsion of governance measures, the high governance costs, high governance efficiency, and the modeling of governance process (Feng Zhifeng, 2007). The costs of campaign-style governance are very high and can easily lead to the waste of resources. Besides, its governance efficiency lacks of continuity and is only a long-term solution. In addition, its governance patterns are against legality; the governance process breeds corrupt behaviors, which exerts serious negative influence on the credit and image of the government. The campaign-style governance mode ignores the multidimensional complexity of social issues and the initiative of social self-management. Hence, there is an urgent need to develop a normalized long-term system design for social governance with the perfection of national basic rights and the reinforcement of market regulation.

According to supply-side reform, the government should stick to the top-level design and roadmap, pay attention to the combination of reform measures, make all the reform measures close up to the central target, and avoid hasty "rigid uniformity". This is no doubt a death sentence for the government's campaign-style governance mode. In fact, the replacement of abnormal short-acting campaign-style governance mode with generalized long-acting governance mode is an inevitable choice of the government. 


\subsection{Control-Stabilization Governance Mode-Stabilization Orientation of Public Service Supply}

The government is acting as the guardian of stability during social governance affected by the mainstream political discourse of "stability overrides everything". Social stability has been long regarded as the most important index of social management in China. In comparison, social fairness, social participation, and social harmony are all ignored. Citizens and other social forces are treated as the objects of governance instead of participants. The exiting communication channels are blocked and citizens are incapable of expressing their reasonable appeals. For example, Chinese government issued the Regulations on Letters and Visits in 2005, but failed to gain expected effects in practical operation. Skiplevel visits are very common since the visitors have doubts about the authority of the basic-level government and want to attract the attention of higher level departments. Skip-level visits have exerted great pressure on the work of capital and superior government departments. Therefore, skip-level visits are strictly prohibited in the Regulations on Letters and Visits. However, the performance evaluation of local government adopts the "one ticket veto" visit policy. In order to refrain from skip-level visits, local governments tend to intercept visits, which seem to achieve short-term and superficial stability, but actually leading to further fermentation of social contradictions.

In such logic, social management is just a mandatory control based on government performance objectives. Under the "forced" pressure of complicated government performance evaluation objectives, the administration takes the mission of social management as the task of stability maintenance. Directed by such working concept, government officials equate social management with stopping "destabilizing". Obviously, the straight-line management idea is not proper for the thorough solution of social issues, or may cause new unstable factors and lead to the vicious circle of stability maintenance governance. A fair and rational communication between the government and the public cannot be realized. Citizens lack an effective interest expression mechanism, and the government is in need of a response mechanism for public appealing. Government's stability maintenance and the public's rights protection become the first cause of social management anomie under the irrational game situation.

\section{Integration of "Addition, Subtraction, Multiplication and Division": Transformation and Upgrading of China's Social Governance Mode in Supply-Side Reform Field}

Numerous cognitive misunderstandings and institutional design flaws such as "universal application", "campaign-style governance", "social exclusion" and "suppressing mode" have been exposed under traditional social management. Despite of the unavoidable upcoming crisis for a certain period, there are also potential opportunities. As early as the 16th National Congress of the CPC, social management and innovation of social management have been placed on the table of important national agenda and advanced to the strategy altitude of the country. The Third Plenary Session of the 18th Central Committee of the CPC 
first proposed the new governing idea of "social governance", stating that the government is no longer a single management subject and the governance process is no longer a top-down and one-way control. The proposition of supplyside structural reform has raised new requirements for the institutional innovation of social governance, and the innovation of economic and social modes of government management is the most important in institutional innovation (Figure 3).

\section{1. "Addiction Effect" of Collaboration: Transformation from Single-Center Governance Mode to Polycentric Governance Mode}

Traditional social management is a monopoly type of management with the government as the single management subject. However, with the advancement and development of modern society, "public institutions function as the promoter, broker or seed capitalists of the market, rather than the mass supplier of specific commodities or labor services." (Osborne \& Gaebler, 2006). In the market economy era featured with competition and selection, effective social governance should be premised on a perfect social self-management mechanism. Except for the function for the country and government, social governance should also encourage the participation of various social forces as social organizations, citizens, and enterprises, etc.

Polycentric governance theory, which is the basis of autonomous system theory of public affairs, proposes to diversify public goods and services, and enroll the competition and selection mechanism into the supply process of public goods and then further into civil entities. Same as public sectors, private sectors and social groups can be also the supply subject of public goods and services. Holistic governance theory emphasizes constructing a cooperation platform between the government and the citizens and establishing an equal partnership between the government and social organizations so that to realize a crossingcomplementing between the administrative functions of the government and the autonomous advantages of the social organizations. All of these theories are based on the fact that the government is not almighty. Mancur Olson mentioned in The Logic of Collective Action that all the efforts will be wasted if we wait the whole group to reach a consensus. But if few people move first, others may

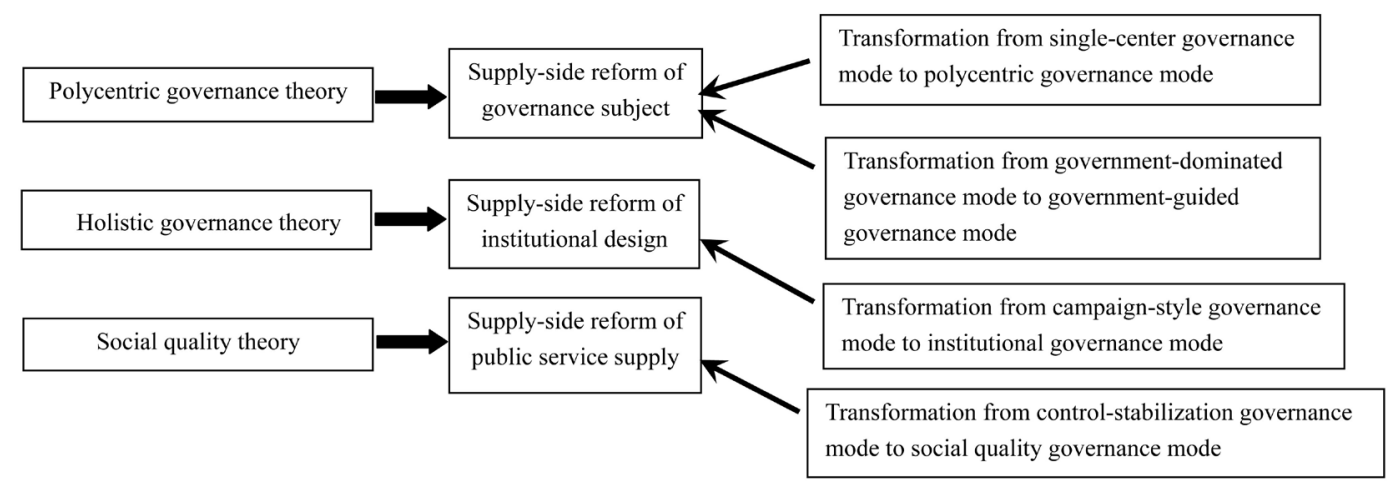

Figure 3. Transformation of social governance mode under the background of supply-side reform. 
follow. Especially for emergencies, not a single government can take on all the rescue and organizational tasks, and diversified social organizations will become an indispensable supporting strength. The participation of various entities in the supply process of public goods and services can eradicate the phenomenon of "free-riding" to some extent and avoid inadequate or excessive supply of public goods or services.

\section{2. "Subtraction Effect" of Intervention: Transformation from Government-Dominated Governance Mode to Government-Guided Governance Mode}

Theoretically, the market should play a decisive role in resource allocation. But in actual situation, the government holds the power of market operation, while enterprises have limited power although they are the main body of economic life. Viewing from the relationship between the government and the market, China still continues the pattern of "market in state"; viewing from the relationship between the government and the society, the phenomenon of "market in state" still keeps unchanged. Under such system, the market and the society are firmly controlled by the government. The development of the market and the society rely too much on the government, and can hardly breathe in such a limited autonomous space. Zhang Kangzhi showed that a control-oriented government cannot realize a real stable and harmonious society, and the government which takes control as its duty will often get caught in "control paradox". If the government maintains the social order by strengthening control, they will feel short of power, and will keep increasing control institutions and personnel due to the lack of control. The pursuit of control will trigger the expanding of the government frame, weaken the control ability of the government, and get the government out of control.

One of the objectives of supply-side reform is to reduce administrative intervention and let the market mechanism better play its decisive role. However, "whoever started the trouble should end it". The government should conduct a self-revolution to realize its target. Government's streamline administration and delegate power doesn't mean to leave alone everything, but to combine "delegate" and "control", establish government power list system, draw a line for government's power to realize "forbidden without authorization", and establish negative list system for market entry. Out of the negative list, each market entities can enter the market legally and equally to realize "all can be done except for those prohibited".

\section{3. "Multiplication Effect" of Institutional Innovation: Transformation from Campaign-Style Governance Mode to Institutional Governance Mode}

According to different governance methods, governance mode can be divided into campaign-style governance and institutional governance. Campaign-style governance is a non-abnormal social governance mode, which relies on selfconscious mobilization of the governance subject rather than specific institu- 
tional regulations (Xu Xiaolin \& Zhu Guowei, 2011). For historical reasons, China's campaign-style governance is mainly performed by "rectification", "reorganization", and "special renovation". These methods are preferred by the government due to their features of short period and high effectiveness. However, the Chinese style campaign-style governance mode is still an abnormal social governance method. The attitude to public issues showed the "idle" thinking of the government sector implementing campaign-style governance. Usually, they will roll out their governance policies in a high pressure way in a short period of time, attempting to put things right once and for all through a short period of concentrated treatment. As soon as the public issues were controlled, the campaign-style governance will be abandoned.

Institutional governance means that the governance subject mainly relies on the authority conferred by law, and deals with public issues based on institutional principles (Wang Dahai \& Zhang Yulei, 2013). Different from campaign-style governance, institutional governance is a normal and institutionalized public governance mode featured with long-term, sustainable and stable inherent properties. Weber believed that modern organizations are formed with efficient and accurate operation methods required by mass production, which are based on rational-legal authority. The management of the organization relies on formal laws or regulations rather than personal authority of the governance subject. To get rid of the disadvantages of campaign-style governance, the governance subject should continuously promote the formalization, institutionalization and standardization of governance to reduce its dependence on the personal factors of the leader, and make the campaign-style governance a more effective social governance mode.

\section{4. "Division Effect" of Mandatory Control: Control-Stabilization Governance Mode to Social Quality Governance Mode}

Social governance can be conducted either by rigid methods as legal restrictions and mandatory control or flexible methods as coordination, motivation, consultation, inspiration and encouragement of participation, etc. Social quality theory emphasizes the standard of values such as "social solidarity", "social integration", and "social empowerment". A high-quality society is to lay emphasis on the livelihood of the people during the policy-making process, which should have high social participation, strong social cohesion and good social trust.

Traditional control-stabilization governance mode is strongly linked to the value orientation of pursing personal interests and group interests and maximizing departmental benefits. Under the interests-oriented social governance concept, the government usually adopts "material-oriented" governance methods, the public administration attaches undue importance to market values such as efficiency, departmental protectionism and utilitarianism phenomenon becomes increasingly severe, and the "publicity" of social governance is overwhelmed by market values such as efficiency, effeteness, performances, and indicators, etc. (Table 1) (Ding Huang, 1998) (Jin Taijun, 2006) (Wang Dahai \& Zhang Yulei, 2013). 
Table 1. Evolution of governance concept and core value of public administration.

\begin{tabular}{|c|c|c|}
\hline \multirow{2}{*}{ Administration paradigm } & \multicolumn{2}{|c|}{ The Evolution Process } \\
\hline & Governance concept & Core value of public administration \\
\hline $\begin{array}{c}\text { Traditional Public } \\
\text { Administration (TPA) }\end{array}$ & Top-down governance & Efficiency first \\
\hline $\begin{array}{c}\text { New Public Administration } \\
\text { (NPA) }\end{array}$ & $\begin{array}{l}\text { Participatory } \\
\text { governance }\end{array}$ & Fairness dominated \\
\hline $\begin{array}{c}\text { New Public Management } \\
\text { (NPM) }\end{array}$ & $\begin{array}{l}\text { Performance-based } \\
\text { governance }\end{array}$ & "Three E" and quality orientation \\
\hline $\begin{array}{l}\text { Public Value Management } \\
\text { (PVM) }\end{array}$ & Network governance & $\begin{array}{l}\text { Attach equal importance to efficiency, } \\
\text { fairness and responsibility }\end{array}$ \\
\hline
\end{tabular}

Data resource: reorganized according to the opinions of Wang Dahai, Ding Huang, and Jin Taijun, etc.

In the framework of PVM (Public Value Management), public minds and pubic opinions are the footstone of the survival and development of the government. During the social governance, the administrator should pay attention to the governance concepts and core values such as fairness, responsibility, democracy and quality which are closely related to the public interests, realize the transformation of governance concept from "material-oriented" to "peopleoriented", and "interests" orientation to "public value" orientation, smooth the interests expression mechanism of the public, improve the possibility, fairness and openness of the participation of the public.

\section{Conclusion and Discussion}

The proposition of supply-side structural reform has raised new requirements for the institutional innovation of social governance, and the innovation of economic and social modes of government management is the most important in institutional innovation. Based on the polycentric governance mode theory, the governance subject of government should be transformed into multi-center. The government system design should be transformed into institutional governance mode based on the holistic governance theory. Furthermore, in view of the social quality theory, the control-stabilization governance mode should be converted to the social quality governance mode.

The governance is not a simple yes-no question. There is no absolute truth in the world, and there is no perfect governance mode in any countries. Transformation is not to resist and abandon the original system, but from the traditional mode to find the crux of the problem, then to optimize and perfect the existing system. As Crozier said, society is not a soft dough, which can be manipulated by the manager kneading, nor the solid walls that must be exploded with explosives, but a dynamic movement in the process of the whole, which hid huge energy.

\section{References}

Beck, W., der Maesen, L., Thomese, F., \& Walker, A. (Eds.). (2001). Social Quality: A Vision for Europe. The Hague: Kluwer Law International, 1, 11-14.

Ding Huang. 丁煌. (1998). Seeking the Coordination and Unification of Fairness and Ef- 
ficiency-Comments on the Value Pursuit of Modern Western New Public Administration 寻求公平与效率的协调与统一一评现代西方新公共行政学的价值追求. Chinese Public Administration, 12, 81-84.

Feng Zhifeng. 冯志峰. (2007). Definition and Characteristics of China's Campaign-Style Governance 中国运动式治理的定义及特征. Journal of the Yinchuan Municipal Party College of C.P.C., 2, 29-32.

Jin Taijun. 金太军. (2000). Historical Evolution of Value Orientation of Western Public Administration 西方公共行政价值取向的历史演变. Jianghai Academic Journal, 6, 37-41.

Lin Ka. 林卡. (2010). Social Quality Theory: New Perspective of Studying the Construction of Harmonious Society 社会质量理论: 研究和谐社会建设的新视角. Journal of Renmin University of China, 2, 105-111.

Osborne, D., \& Gaebler, T. (2006). Reinventing Government: How the Entrepreneurial Spirit Is Transforming the Public Sector. Shanghai Translation Publishing House.

Peng Jinpeng. 彭锦鹏. (2005). Holistic and Institutional Governance: Theoretical Strategy 全观型与制度化治理：理论策略. Political Science Review (Taiwan), 23, 22-27.

Quan Zhongxie. 全钟䃞. (2008). The Social Construction of Public Administration: EXplanation and Criticism 公共行政的社会建构: 解释与批评. Trans. Sun Boying et al. Beijing: Peking University Press.

Wang Dahai, \& Zhang Yulei. 汪大海, 张玉否. (2013). From Campaign-Style Governance to Institutional Governance: Governance Mode Selection of New Urbanization 从运动式治理到制度化治理: 新型城镇化的治理模式选择. Exploration and Free Views, 11, 47-50.

Xu Xiaolin, \& Zhu Guowei. 徐晓林, 朱国伟. (2011). Explain and Orientation: Institutionalism Perspective of Campaign-Style Governance-Analysis in the Background of “Mediocre Management and Accountability” 解释与取向: 运动式治理的制度主义视 野——以“治庸问责”风暴为背景的分析. Study and Practice, 8, 86-94.

Zhang Kangzhi. 张康之. (2012). Research on the Transformation of Government Behavior Mode from Control to Guiding 论政府行为模式从控制向引导的转变. Journal of Beijing Administrative College, 2, 22-29.

\section{Submit or recommend next manuscript to SCIRP and we will provide best service for you:}

Accepting pre-submission inquiries through Email, Facebook, LinkedIn, Twitter, etc. A wide selection of journals (inclusive of 9 subjects, more than 200 journals) Providing 24-hour high-quality service User-friendly online submission system Fair and swift peer-review system Efficient typesetting and proofreading procedure Display of the result of downloads and visits, as well as the number of cited articles Maximum dissemination of your research work

Submit your manuscript at: http://papersubmission.scirp.org/

Or contact chnstd@scirp.org 